\title{
Green Accounting Terhadap CSR pada Bus di Indonesia dengan Kinerja Keuangan Sebagai Variabel Intervening
}

\author{
Ulul Azmi Mustofa ${ }^{1)}$, Rezha Nia Ade Putri Edy ${ }^{2)}$, Muhammad Kurniawan ${ }^{3)}$, \\ Muhammad Fikri Nugraha Kholid ${ }^{4)}$ \\ ${ }^{1,2,3,4}$ Fakultas Ekonomi dan Bisnis Islam, UIN Raden Intan Lampung \\ *Email korespondensi: ululazmimsi@gmail.com
}

\begin{abstract}
Abstrak
Sustainbility reporting merupakan konsep pelaporan keuangan pada perbankan yang memberikan informasi meliputi aspek ekonomi, sosial dan lingkungan dengan memperhatikan aspek keberlanjutan bisnis bank, sehingga bank tersebut menjadi bank yang ramah lingkungan serta memperoleh legitimasi sosial dari para stakeholder. Penelitian ini bertujuan untuk mengetahui apakah ada pengaruh green accounting terhadap CSRDi dan Kinerja Keuangan, pengaruh kinerja keuangan terhadap CSRDi, green accounting terhadap CSRDi dengan kinerja keuangan sebagai variabel intervening, dan bagaimana konsep green accounting terhadap CSRDi dan kinerja keuangan pada Bank Umum Syariah dalam perspektif Islam. penelitian ini menggunakan pendekatan kuantitatif deskriptif dengan menggunakan analisis regresi linear berganda dan analisis jalur. Populasi dan Sampel dalam penelitian ini seluruh Bank Umum Syariah periode tahun 2015-2018 yang memenuhi kriteria. Variabel dependennya $(X)$ yaitu green accounting dengan metode dummy, variabel independennya $(Y)$ yaitu CSR disclosure dengan indikator pengungkapan CSR versi G.R.I 3.0, dan variabel intervening (Z) yaitu kinerja keuangan yang dihitung menggunakan rasio ROA. Hasil penelitian ini adalah green accounting berpengaruh positif dan signifikan terhadap CSRDi dan kinerja keuangan dibuktikan dengan nilai coefficient 0,459 dan prob 0.0008, kinerja keuangan berpengaruh positif dan signifikan terhadap CSRDi dibuktikan dengan nilai coefficient 0,236 dan prob 0,524, kinerja keuangan bukan merupakan variabel intervening pada green accounting terhadap CSRDi dibuktikan dengan pengaruh langsung sebesar 0,459 sedangkan besarnya pengaruh tidak langsungnya yaitu $(P 1 a) \times(P 2 b)=(0,330) \times(0,236)=0,078$, green accounting terhadap CSRDi pada BUS sudah sesuai dengan perspektif Islam baik dalam pelaksanaan maupun penilaiannya.
\end{abstract}

Keywords : Green Accounting, Corporate Social Responsibility Disclosure (CSRDi), Kinerja Keuangan, Return On Assets (ROA).

\begin{abstract}
Sustainability reporting is a financial reporting concept in banks that provides information covering economic, social and environmental aspects by taking into account the sustainability of the bank's business, so that the bank becomes an environmentally friendly bank and gains social legitimacy from stakeholders. This study aims to determine whether there is an effect of green accounting on CSRDi and financial performance, the effect of financial performance on CSRDi, green accounting on CSRDi with financial performance as an intervening variable, and how the concept of green accounting on CSRDi and financial performance at Islamic Commercial Banks in Islamic perspective. . This study uses a descriptive quantitative approach using multiple linear regression analysis and path analysis. Population and sample in this study are all Islamic Commercial Banks for the period 2015-2018 that meet the criteria. The dependent variable $(X)$ is green accounting with the dummy method, the independent variable $(Y)$ is CSR disclosure with the G.R.I 3.0 version of the CSR disclosure indicator, and the intervening variable $(Z)$ is financial performance calculated using the ROA ratio. The results of this study are green accounting has a positive and significant effect on CSRDi and financial performance with coefficient 0,459 and prob 0.0008, financial performance has a positive and significant effect on CSRDi with coefficient 0,236 dan prob 0,524, financial performance is not an intervening variable on green accounting for CSRDi with $(P 1 a) \times(P 2 b)=(0,330) \times(0,236)=0,078$, green accounting for CSRDi on BUS is in accordance with the Islamic perspective both in implementationandassessment.
\end{abstract}

Keywords: Green Accounting, Corporate Social Responsibility Disclosure (CSRDi), Financial Performance, Return On Assets (ROA) 
Saran sitasi: Mustofa, U. A., Edy, R. N. A. P., Kurniawan, M., \& Kholid, M. F. N. (2020). Green Accounting Terhadap CSR pada Bus di Indonesia dengan Kinerja Keuangan Sebagai Variabel Intervening. Jurnal Ilmiah Ekonomi Islam, 6(03), 508-520. doi:http://dx.doi.org/10.29040/jiei.v6i3.1372

\section{DOI: http://dx.doi.org/10.29040/jiei.v6i3.1372}

\section{PENDAHULUAN}

Permasalahan lingkungan yang sering terjadi tidak lepas dari campur tangan manusia, dimana kerusakan ini banyak ditimbulkan dari kegiatan usaha manusia dalam rangka memperoleh keuntungan. Sumber daya lingkungan seperti udara, air, lahan, dapat menyediakan barang dan jasa yang secara langsung maupun tidak langsung mendapatkan manfaat ekonomis. Perbankan dan lingkungan dalam beberapa hal cenderung berlawanan. Bank adalah institusi profit oriented sedangkan lingkungan adalah suatu sistem yang tidak bernilai financial. Meskipun perbankan dan lingkungan berada dalam dua dunia yang berbeda tetapi keduanya memiliki kepentingan yang sama yaitu sustainability, sehingga diperlukan komitmen dan kerja sama dalam mencapai kepentingan tersebut dengan mengintegrasikan aspekaspek pengelolaan lingkungan dan sosial yang dapat dituangkan dalam laporan keuangan dengan memakai konsep green accounting yakni menerapkan dan memberikan informasi yang mengintegrasikan aspek lingkungannya pada laporan keuangannya.(Andreas Lako, 2014 : 112)

Desi Mariani (2017) menyatakan pembangunan yang terus berkembang yang terjadi di kota besar di Indonesia sangatlah berpengaruh terhadap kestabilan kondisi lingkungan. Semakin meningkatnya pembangunan akan menyebabkan semakin meningkatnya dampak terhadap lingkungan. Keadaan ini mengindikasikan diperlukannya adanya upaya pengendalian dampak lingkungan hidup. Selain itu Darwin (2007) menyatakan bahwa salah satu tujuan perusahaan dalam mengungkapkan kinerja lingkungan, sosial dan finansial di dalam laporan tahunan atau laporan terpisah adalah untuk mencerminkan tingkat akuntabilitas, responsibilitas dan transparansi korporat kepada investor dan stakeholder lainnya, dimana pengungkapan tersebut bertujuan untuk menjalin hubungan komunikasi yang baik dan efektif antara perusahaan dengan publik dan stakeholder lainnya tentang bagaimana perusahaan telah mengintegrasikan CSR dan lingkungan sosial dalam setiap aspek kegiatan operasinya.

Konsep green accounting pada dasarnya mendorong agar setiap kegiatan pelaporan keuangan kegiatan ekonomi dapat meminimalkan dampaknya bagi lingkungan yang juga diterapkan pada dunia perbankan karena dengan perbankan akan memberikan informasi tentang tanggung jawab akan lingkungan, biaya-biaya serta risiko pada lingkungan di pelaporan keuangannya maka perbankan perbankan ikut meminimalisir kerusakan lingkungan yang merupakan suatu bentuk tanggung jawab perusahaan dalam perekonomian berkelanjutan, dengan demikian akan lebih menarik investor dalam berinvestasi dan otomatis akan menambahkan laba bagi perusahaan. Semua prestasi keuangan yang telah dicapai perusahaan tergambar dalam laporan keuangan dan kinerja keuangan menggambarkan usaha perusahaan (operation income). Selain itu Fitria Puji Astuti (2014) menyatakan probability suatu perusahaan dapat diukur dengan menghubungkan keuntungan yang diperoleh dari kegiatan pokok perusahaan dengan kekayaan asset yang digunakan untuk menghasilkan keuntungan.

Saat ini, Bank Indonesia telah mengeluarkan kebijakan untuk mendorong fungsi Intermediasi dan keuangan inklusif sejalan memasukkan aspek lingkungan hidup. Perbankan memerlukan arah dan kebijakan yang jelas dan aturan yang memadai sehingga perbankan mampu mendukung pembangunan yang berkelanjutan. Penerapan prinsip tersebut dalam perbankan dikenal yang dengan istilah Green Banking yang penerapannya secara implisit tertuang dalam PBI No.8/21/PBI/2006 dan surat edaran Bank Indonesia No.8/22/DPbS. Serta pada POJK Nomor 51/POJK.03/2017 tentang penerapan keuangan berkelanjutan bagi lembaga jasa keuangan, emiten, dan perusahaan publik. Bank syariah dalam pelaporan keuangan kegiatan bisnisnya tidak hanya terfokus pada transaksi keuangan saja, akan tetapi diperluas dengan mencakup transaksi sosial dan lingkungan yakni dengan konsep Green Accounting. Dalam bank syariah, pelaporan keuangan kinerja lingkungan ini diungkapkan sebagai tanggung jawab sosial perusahaan atau Corporate Social Responsibility Disclosure (CSRDi). Dimana konsep ini adalah sebuah strategi bisnis jangka panjang yang didasari tiga aspek orientasi, yaitu profit (keuntungan), people (hubungan sosial masyarakat), 
serta planet (lingkungan hidup). Istilah tersebut sering dikenal dengan triple bottom line. Dengan memberikan informasi manajerial yang bermanfaat yang meliputi biaya lingkungan secara tepat maka akan dapat diketahui bagaimana efisiensi perbankan dalam mengelola asetnya sehingga berperan dalam perekonomian berkelanjutan. Para stakeholders juga dapat mengetahui dan menilai kinerja dan korporasi serta risiko dan prospek secara utuh sebelum mengambil keputusan. Green accounting dalam pelaporan keuangan praktik bisnisnya adalah suatu institusi keuangan yang memberikan prioritas pada sustainnbility. (Setyo Budiantoro, 2014 : 112)

Pertumbuhan pelaporan keberlanjutan pada industri lembaga keuangan yang kurang diterapkan atau dapat dikatakan hanya bersifat sukarela saja, padahal jika lembaga keuangan lebih menerapkan laporan keberlanjutan yang memberikan informasi meliputi kinerja lingkungan maka lembaga keuangan akan memiliki peluang besar untuk lebih berkembang kearah perusahaan berkelanjutan. Namun, pelaporan keberlanjutan yang masih bersifat sukarela, membuat entitas dalam industri perbankan tidak memiliki prioritas untuk menyajikannya. Bank yang telah mendeklarasikan pelaporan konsep green pada Corporate Social Responsibility Disclosure (CSRDi) harus diterapkan dengan baik dan matang pada Core Business Competence-nya, sehingga penerapan pelaporan keuangannya akan dapat diketahui lebih jelas oleh para stakeholders. Perbankan memiliki potensi yang tinggi sebagai role model bagi industri lainnya dalam menerapkan prinsip-prinsip Sustainable Development. (Andi Nurul Fadhilah Ayu, Maria Anityasari, 2013 : 1-6)

Perusahaan melaksanakan tanggung jawab terhadap lingkungan untuk menciptakan pembangunan berkelanjutan yang dapat dilihat dari pengungkapan tanggung jawab sosial dan lingkungan hidup pada pelaporan keuangan bank syariah, sehingga dapat diketahui bagaimana bank dapat mengelola aset perbankan agar lebih efisien, karena semakin tinggi biaya yang harus dikeluarkan perbankan salah satunya adalah biaya untuk lingkungan. Biaya yang semakin tinggi tersebut akan semakin mengurangi pendapatan perbankan dan profitabilitas bank akan menurun. (Tria Ratnasari, Arni Surwanti, Firman Pribadi : 1-15) Mengenai dengan informasi meliputi kinerja lingkungan, biaya biaya serta risiko lingkungan pada pelaporan keuangan yang merupakan suatu pelaksanaan pengungkapan tanggung jawab sosial dan lingkungan perusahaan. Maka, akan dapat diketahui bagaimana perusahaan dalam mengelola asetnya agar semakin efisien sehingga akan lebih banyak menghasilkan laba. Penelitian mengenai green accounting terhadap pengungkapan tanggung jawab sosial dan lingkungan pada perusahaan yang dilihat dari bagaimana kinerja keuangan dalam efisiensi pengelolaan asetnya pada pelaporan keuangan yang masih belum banyak dilakukan di Indonesia, sehingga penelitian ini perlu dilakukan untuk dapat memberikan hasil berupa pengetahuan mengenai manfaat penerapan green accounting terutama penulis ingin mengetahui seberapa besar pengaruh green accounting pada Corporate Social Responsibility Disclosure (CSRDi) dengan kinerja keuangan sebagai variabel intervening terkait Return On Assets (ROA) untuk melihat bagaimana perbankan dalam mengelola asetnya agar lebih efisien. (Widya Novita Sari, Puspita Rani, 2015: 1-20)

Peran bisnis hijau dalam Islam terhadap tanggung jawab pada sebuah perusahaan merupakan suatu yang telah menjadi keharusan untuk dapat dilaksanakan agar usaha ataupun bisnis lebih berkembang dengan tetap menjaga kelestarian alam dan lingkungan sekitarnya. (Muhammad, 2004 : 133) Oleh karena ini segala usaha baik bisnis ataupun bukan bisnis menjaga kelestarian alam sekitar merupakan sebuah keharusan. Sejumlah bank syariah di Indonesia sudah aktif dalam menyediakan pelaporan yang juga menunjukan tentang kinerja lingkungan perusahaan (green accounting), ada beberapa bank syariah yang sudah mulai menyertakan laporan mengenai pembiayaan berkelanjutan dalam laporan tahunannya.. Berdasarkan uraian-uraian dalam latar belakang diatas , maka yang menjadi rumusan masalah dalam penelitian ini adalah :

a. "Bagaimana pengaruh Green Accounting terhadap CSR Disclosure dan Kinerja Keuangan pada Bank Umum Syariah?

b. Bagaimana pengaruh Kinerja Keuangan terhadap CSR Dislosure pada Bank Umum Syariah?

c. Bagaimana pengaruh Green Accounting terhadap CSR Disclosure pada Bank Umum Syariah dengan Kinerja Keuangan sebagai Variabel Intervening? "Serta Bagaimana konsep penerapannya menurut perspektif Islam?

d. Bagaimana penerapan Green accounting terhadap CSR Disclosure dan kinerja keuangan menurut perspektif ekonomi Islam? 


\section{Jurnal Ilmiah Ekonomi Islam, 6(03), 2020, 511}

\section{Landasan Teori}

\section{Teori Maqashid Al-syariah}

a. Maqashid Al-Syariah merupakan landasan penting dalam menegakkan tiang agama yakni kemaslahatan yang adapun hasil dari kemaslahatan tersebut menjadi 5 kemaslahatan untuk dilindungi. Penetapan hukum dalam Maqashid Al-Syariah ini juga ditentukan dengan beberapa alasan yang berguna untuk menyelesaikan kemaslahatan yang ada. Maqashid $A l$-Syariah ini memiliki peranan penting dalam proses terjadinya hukum. Penetapan dalam menentukan dasar hukum Maqashid Al-Syariah bisa dinyatakan secara spesifik sebagai tujuan dari syariat melalui tiga cara penetapan, menurut AshSyatibi tiga cara penetapan itu adalah :

b. Dengan mengetahui dalil perintah atau larangan secara jelas, bahwa tujuan yang dikehendaki adalah kepatuhan dengan menjalankan perintah dan meninggalkan larangan.

c. Dengan memandang alasan dari perintah atau larangan, seperti pensyariatan nikah yang bertujuan untuk memelihara keturunan.

d. Dalam penerapan hukum syari'at, syar'i memiliki tujuan pokok (Maqashid Ashliyyah) dan tujuan pelengkap (Maqashid Tabi'ah).

Tertera secara eksplisit, tersirat secara implicit, ataupun didapatkan dari hasil penelusuran (istiqra') terhadap nash. Sehingga dapat disimpulkan bahwa setiap Maqashid yang tidak tertera dalam nash namun tidak bertentangan dengan ketentuan diatas, maka termasuk dalam Maqashid Al-Syariah. (Abu Ishaq Ibrahim bin Musa bin Muhammad Allakhmy AsSyatiby, 2003 : 78) Adapun pokok dalam kemaslahatan yang menjadi dasar dalam maqashid alsyariah sebagai tujuan syariah, seperti yang telah dihitung juga oleh ulama dengan nama al-kulliyat al khams (lima hal ini/pokok) yang mereka anggap sebagai dasar-dasar dan tujuan syariat yang harus dijaga, yakni :

a. Kemaslahatan Dharurriyah (Inti/Pokok), yaitu kemaslahatan Maqashid Al-Syariah yang berada dalam urutan paling atas.

b. Kemaslahatan Ghairu Dharurriyah (Bukan kemaslahatan pokok), namun kemaslahatan ini tergolong penting dan tidak bisa dipisahkan. (Abu Ishaq Ibrahim bin Musa bin Muhammad Allakhmy AsSyatiby, 2003 : 78)

c. Adapun unsur-unsur Maqashid Syariah syariat yang berhubungan dengan hal-hal yang bersifat kebutuhan primer manusia (maqashid addharuriyat), yakni:

1) Memelihara Agama Agama merupakan persatuan aqidah, ibadah, hokum, dan undang-undang yang telah disediakan oleh Allah SWT untuk mengatur hubungan manusia dengan Tuhannya (hubungan vertikal), dan hubungan antara sesama manusia (hubungan horizontal). Agama Islam juga merupakan nikmat Allah yang tertinggi dan sempurna.

2) Memelihara Jiwa Islam melarang pembunuhan dan pelaku pembunuhan diancam dengan hukum Qiyas (pembalasan yang seimbang), Diyat (denda) dan Kafarat (tebusan) sehingga dengan demikian diharapkan agar seseorang sebelum melakukan pembunuhan, berfikir secara dalam terlebih dahulu karena jika yang dibunuh mati atau jika yang dibunuh cedera, maka pelakunya akan cedera yang seimbang dengan perbuatan nya.

3) Memelihara akal Manusia adalah makhluk yang paling sempurna di antara makhluk ciptaan Allah yang lainnya. Allah telah menciptakan manusia dengan sebaik-baik bentuk, dan melengkapi bentuk itu dengan akal.

4) Memelihara keturunan Islam telah mengatur pernikahan dan mengharamkan zina, menetapkan siapa-siapa yang tidak boleh dikawini, sebagaimana cara cara perkawinan itu dilakukan dan syarat apa yang harus dipenuhi sehingga perkawinan itu dianggap sah dan pencampuran antara dua manusia yang berlawanan jenis itu tidak dianggap zina dan anak-anak yang lahir dari hubungan itu dianggap sah dan menjadi keturunan dari ayahnya.

5) Memelihara harta benda Meskipun pada hakikatnya semua harta benda adalah milih Allah SWT, namun Islam juga mengakui hak pribadi seseorang. Oleh karena manusia sangat tama' kepada harta benda, dan mengusahakannya melalui jalan apapun, maka Islam mengatur supaya jangan sampai terjadi bentrokan antara satu sama lain. (Muhammad Djakfar,2007 : 160-163)

Dengan demikian inilah yang menjadi landasan maqashid al-syariah menjadi dasar teori syariah dalam 
menerapkan pelaporan keuangan yang memberikan informasi kinerja lingkungan, biaya -biaya serta risiko lingkungan pada Bank Umum Syariah. Adapun implementasi Corporate Social Responsibility dalam islam secara rinci harus memenuhi beberapa unsur, yakni:

a. Al-Adl

Dalam beraktivitas di dunia bisnis, Islam mengharuskan berbuat adil di yang diarahkan kepada orang lain, hak lingkungan sosial, dan hak alam semesta. Jadi, keseimbangan alam dan keseimbangan sosial harus tetap terjaga bersamaan dengan operasional usaha bisnis.

b. Al-Ihsan

Ihsan merupakan perbuatan baik tanpa adanya kewajiban tertentu untuk melakukan sesuatu hal. Implementasi Corporate Social Responsibility dengan semangat Ihsan akan dimiliki ketika individu atau kelompok melakukan kontribusi dengan semangat ibadah dan berbuat atas dasar mendapat ridho Allah.

c. Manfaat

Konsep manfaat dalam Corporate Social Responsibility lebih dari aktivitas ekonomi perusahaan sudah seharusnya memberikan manfaat yang lebih luas dan tidak statis namun harus dinamis misalnya terkait dengan berbagai aspek sosial seperti pendidikan, kesehatan, pemberdayaan masyarakat, dan pelestarian lingkungan.

d. Amanah

Perusahaan yang menerapkan Corporate Social Responsibility, harus memahami dan menjaga amanah dari masyarakat misalnya dengan menghindari perbuatan yang tidak terpuji dalam setiap aktivitas bisnis.

(MuhammadDjakfar,2007:160-163)

\section{Teori Legitimasi}

Teori legitimasi merupakan suatu teori yang berada pada kerangka teori ekonomi politik yang memberikan pengaruh pada masyarakat agar dapat menentukan alokasi sumber keuangan dan sumber ekonomi lainnya, perusahaan cenderung menggunakan kinerja berbasis legitimasi karena merupakan hal penting dalam perkembangan perusahaan kedepannya. Dasar pemikiran teori legitimasi adalah organisasi yang akan terus berlanjut keberadaannya jika masyarakat menyadari bahwa organisasi beroperasi untuk sistem nilai yang sejalan pada sistem nilai masyarakat. Teori legitimasi menjelaskan bahwa praktik pengungkapan tanggung jawab sosial perusahaan harus dilaksanakan sebaik mungkin agar nantinya aktivitas dan kinerja perusahaan mendapat respon yang baik masyarakat. Adapun dengan respon positif tersebut akan dapat melahirkan nilai yang baik perusahaan dimata masyarakat dan otomatis dapat meningkatkan pencapaian laba oleh pihak perusahaan. Tentu hal ini akan menjadi keuntungan bagi perusahaan, karena dengan nilai yang sudah terbangun, akan bisa memberikan ketertarikan pada pihak investor untuk mau berinvestasi di perusahaan. (Edoardus Satya Adhiwardana dan Daljono, 2013 : 1-12)

\section{Teori Stakeholder}

Stakeholders merupakan keterikatan yang didasari oleh kepentingan tertentu. Dengan demikian, jika berbicara mengenai stakeholder theory berarti membahas hal-hal yang berkaitan dengan kepentingan berbagai pihak. Teori stakeholder adalah bahwa stakeholder merupakan sistem yang secara eksplisit berbasis pada pandangan tentang suatu organisasi dan lingkungannya, mengenai sifat saling mempengaruhi antara keduanya yang kompleks dan dinamis. Stakeholder dan organisasi saling mempengaruhi, hal ini dapat dilihat dari hubungan sosial keduanya yang berbentuk responsibilitas dan akuntabilitas. Oleh karena itu organisasi memiliki akuntabilitas terhadap stakeholdernya. Teori stakeholder mengatakan bahwa perusahaan bukanlah entitas yang hanya beroperasi untuk kepentingannya sendiri namun harus memberikan manfaat bagi stakeholdernya. (Chariri A dan Ghozali Imam, 2007 : 29) Teori stakeholder pada suatu perusahaan diharapkan dapat memberi manfaat bagi stakeholder. Manfaat tersebut dapat diberikan dengan cara menerapkan Corporate Social Responsibility (CSR) dengan adanya program tersebut perusahaan diharapakan akan dapat meningkatkan kesejahteraan karyawan, pelanggan dan masyarakat lokal. Sehingga akan dapat terjalin hubungan yang baik antara perusahaan dengan lingkungan sekitar tempat beroperasi. (Ersi Sisdianto dan Ainul Fitri, $2020: 9-24)$

\section{Green Accounting}

Akuntansi lingkungan merupakan suatu ilmu yang dipengaruhi dan mempengaruhi lingkungannya. Eksistensinya tidak bebas nilai terhadap perkembangan masa. Metode-metode pembukuan juga terus berkembang mengikuti kompleksitas bisnis 
yang semakin tinggi. Ketika kepedulian terhadap lingkungan mulai mendapat perhatian masyarakat, akuntansi berbenah diri agar siap menginternalisasi berbagai eksternalitas. Melalui penerapan green accounting pada pelaporan keuangan tahunan perusahaan maka diharapkan lingkungan akan terjaga kelestariannya, karena dalam menerapkan green accounting maka perusahaan akan secara sukarela mamatuhi kebijakan pemerintah tempat perusahaan tersebut menjalankan bisnisnya, karena dengan adanya pengungkapan pengungkapan semua biaya lingkungan, baik internal maupun eksternal, dan mengalokasikan biaya-biaya ini berdasarkan tipe biaya dan pemicu biaya dalam sebuah akuntansi lingkungan yang terstruktur akan menmberikan kontribusi baik pada kinerja lingkungan. (Chariri A dan Ghozali Imam, $2007: 31$ )

\section{Corporate Social Responsibility Disclosure}

Tanggung jawab sosial perusahaan atau Corporate Social Responsibility merupakan perluasan tanggung jawab perusahaan dari tanggung jawab ekonomi atas pengelolaan dana yang diinvestasikan, yang pelaksanaannya disampaikan melalui laporan keuangan, menjadi perusahaan yang juga memiliki tanggung jawab sosial dan lingkungan, yang pelaksanaannya disampaikan melalui laporan tanggung jawab sosial. Konsep tanggung jawab keuangan, sosial, dan lingkungan ini dikenal dengan konsep Triple Bottom Line (3P: People, Planet, Profit). (Muhammad Yasir Yusuf, 2017 : 43).

Corporate Social Responsibility Disclosure atau pengungkapan merupakan suatu proses penyedia informasi yang dirancang untuk mengemukakan masalah seputar social accountability, yang mana secara khas tindakan ini dapat dipertanggungjawabkan dalam media-media seperti laporan tahunan maupun dalam bentuk iklan yang berorientasi sosial. (Nurdizal, Asef Efendi, Emir Wicaksana, $2011: 9$ )

\section{Return On Assets (ROA)}

Return On Assets (ROA) merupakan rasio profitabilitas yang menunjukkan perbandingan antara laba (sebelum pajak) dengan total asset bank. Return On Asset (ROA) memberikan gambaran tentang kemampuan pimpinan bank mengoperasikan harta bank yang dipercayakan kepada mereka untuk mencari keuntungan. Rasio profitabilitas ini sekaligus menggambarkan efisiensi kerja bank yang bersangkutan. Return On Asset (ROA) merupakan perbandingan antara laba sebelum pajak dengan ratarata total asset dalam masa tertentu dengan jumlah harta yang dimiliki. Return On Asset (ROA) bertujuan mengukur keberhasilan manajemen dalam menghasilkan laba. Semakin kecil rasio ini mengindikasikan kurangnya kemampuan manajemen bank dalam hal mengelola aktiva untuk meningkatkan pendapatan dan atau menekan biaya. (Siswanto Sutojo, 2007 : 57) Alasan dipilihnya Return On Asset (ROA) sebagai pengukuran kinerja keuangan ini adalah karena Return On Asset (ROA) digunakan untuk mengukur kemampuan manajemen bank dan efisiensi aset bank untuk memperoleh keuntungan secara keseluruhan. Jadi semakin tinggi tingkat Return On Asset (ROA) bank, menunjukan semakin tinggi pula tingkat profitabilitas bank tersebut, dan semakin baik pula posisi bank dari segi penggunaan aset.

\section{Pengembangan Hipotesis}

Pengaruh Green Accounting terhadap Kinerja Keuangan pada Bank Umum Syariah di Indonesia

Pembebanan biaya lingkungan pada produk dapat menghasilkan informasi manajerial yang bermanfaat. Dengan membebankan biaya lingkungan secara tepat maka akan diketahui apakah suatu produk menguntungkan atau tidak. Sehingga akan mempengaruhi efisiensi ekonomi perusahaan. Penelitian yang dilakukan Anis Fitriani (2013) dan Nurika Restuningdiah (2010) yang menyatakan bahwa kinerja lingkungan berpengaruh positif terhadap kinerja keuangan. Berdasarkan landasan tersebut, maka hipotesis pertama dalam penelitian ini adalah :

$\mathrm{H}^{0}$ : Tidak terdapat pengaruh Green Accounting terhadap Kinerja Keuangan pada Bank Umum Syariah di Indonesia. $\mathrm{H}^{1}$ :Terdapat pengaruh. Green Accounting terhadap Kinerja Keuangan pada Bank Umum Syariah di Indonesia.

\section{Pengaruh Green Accounting terhadap Corporate Social Responsibility Disclosure pada Bank Umum Syariah di Indonesia}

Perusahaan sangat perlu untuk melaporkan kegiatan aktivitas perusahaan. Dalam pelaporan mengenai informasi kebijakan dan sasaran-sasaran lingkungannya, program-program yang sedang dilakukan dan biaya biaya yang terjadi karena tujuan dalam menyiapkan serta mengungkapkan risiko-risiko lingkungan. Dimana pengungkapan aktifitas 


\section{Jurnal Ilmiah Ekonomi Islam, 6(03), 2020, 514}

lingkungan perusahaan sebagai perwujudan Corporate Social Responsibility dapat dimasukkan dalam laporan keuangan, catatan atas laporan keuangan misalkan dalam bentuk laporan berkelanjutan atau sustainability reporting. Dalam penelitian yang dilakukan oleh Tino Anindito dan Didik Ardianto (2012) berpendapat bahwa kinerja lingkungan berpengaruh positif terhadap pengungkapan Corporate Social Responsibility. Berdasarkan landasan tersebut, maka hipotesis kedua dalam penelitian ini adalah :

$\mathrm{H}^{0}$ : Tidak terdapat pengaruh Green Accounting terhadap Corporate Social Responsibility Disclosure pada Bank Umum Syariah di Indonesia.

$\mathrm{H}^{2}$ : Terdapat pengaruh. Green Accounting terhadap Corporate Social Responsibility Disclosure pada Bank Umum Syariah di Indonesia.

\section{Pengaruh Kinerja Keuangan terhadap Corporate Social Responsibility Disclosure pada Bank Umum Syariah di Indonesia.}

Perusahaan yang menerapkan CSR dengan baik, maka perusahaan diharapkan akan memperoleh legitimasi sosial dan memaksimalkan kekuatan keuangannya dalam jangka panjang yang akan memperoleh respon positif para pelaku pasar karena mengungkapkan informasi keuangan yang berkaitan dengan lingkungan akan lebih menarik para pengguna laporan keuangan yang akan menaikkan kinerja ekonomi perusahaan yang bersangkutan sehingga para stakeholder maupun pengguna laporan keuangan akan lebih tertarik terhadap perusahaan. Dalam penelitian yang dilakukan oleh Sari (2012) berpendapat bahwa kinerja keuangan berpengaruh terhadap pengungkapan CSR. Berdasarkan landasan tersebut, maka hipotesis ketiga dalam penelitian ini adalah :

$\mathrm{H}^{0}$ : Tidak terdapat pengaruh Kinerja Keuangan terhadap Corporate Social Responsibility Disclosure pada Bank Umum Syariah di Indonesia.

$\mathrm{H}^{3}$ : Terdapat pengaruh Kinerja Keuangan terhadap Corporate Social Responsibility Disclosure pada Bank Umum Syariah di Indonesia.

Pengaruh Green Accounting terhadap Corporate Social Responsibility Disclosure pada Bank Umum Syariah di Indonesia periode tahun 2015-2016 dengan Kinerja Keuangan sebagai Variabel Intervening.
Perusahaan yang menerapkan green accounting atau sustainbility reporting akan lebih banyak mengungkapkan aktivitas sosial dan lingkungan, sehingga secara tidak langsung akan menarik para investor dan dapat membantu perusahaan dalam meningkatkan kinerja keuangannya. Dengan mengungkapkan informasi keuangan yang berkaitan dengan lingkungan akan lebih menarik para pengguna laporan keuangan sehingga akan menaikkan kinerja ekonomi perusahaan yang bersangkutan sehingga para stakeholder maupun pengguna laporan keuangan akan lebih tertarik terhadap perusahaan dengan begitu dapat juga meningkatkan nilai perusahaan. Dalam penelitian yang dilakukan oleh Mazda Eko Sri Tjahjono (2013) berpendapat bahwa Kinerja lingkungan memiliki pengaruh secara tidak langsung terhadap nilai perusahaan melalui kinerja keuangan. Berdasarkan landasan tersebut, maka hipotesis keempat dalam penelitian ini adalah : Berdasarkan landasan tersebut, maka hipotesis keempat dalam penelitian ini adalah : $\mathrm{H}^{0}$ : Tidak terdapat pengaruh Kinerja Keuangan secara tidak langsung pada Green Accounting terhadap Corporate Social Responsibility Disclosure pada Bank Umum Syariah di Indonesia.

$\mathrm{H}^{4}$ : Terdapat pengaruh Kinerja Keuangan secara langsung pada Green Accounting terhadap Corporate Social Responsibility Disclosure pada Bank Umum Syariah di Indonesia.

\section{METODE PENELITIAN}

\subsection{Populasi dan Sampel}

Populasi pada penelitian ini yaitu seluruh bank umum syariah yang ada di Indonesia yang belum ataupun sudah memberikan informasi lingkungan berdasarkan indikator kinerja lingkungan pengungkapan tanggung jawab sosial GRI versi 3.0 pada pelaporan keuangan tahunannya, selama periode 2015-2018. Dalam proses pengambilan sampel mempunyai beberapa kriteria. Adapun sampel penelitian tersebut, diantaranya: (1) Laporan Tahunan Bank Umum Syariah periode 2015-2018, (2) Bank Umum Syariah harus menerapkan Green Accounting sesuai dengan Indikator Kinerja Lingkungan pada pengungkapan CSR GRI versi 3.0. Adapun jumlah sampel penelitian pada penelitian ini berjumlah 9 dari 14 bank umum syariah yang ada di Indonesia. Teknik sampel yang akan digunakan oleh peneliti dalam melakukan penelitiannya adalah Non Probability Sampling. 


\subsection{Operasional Variabel}

a. Variabel Independen

Variabel Independen yakni Green Accounting dapat diukur dengan menggunakan metode dummy yaitu Jika suatu perusahaan memiliki salah satu komponen biaya lingkungan biaya operasional lingkungan, biaya daur ulang produk dalam biaya pengembangan dan penelitian lingkungan dalam laporan tahunan (Annual Report) maka akan diberi angka 1 (satu), tetapi jika tidak diberi angka 0 (nol). Metode pengukuran diatas berdasarkan pengukuran yang telah dilakukan oleh Desy Mariani (2017)

\section{b. Variabel Dependen}

Variabel dependen yakni Corporate Social Responsibility Disclosure dengan menggunakan indikator dari Global Reporting Initiative (GRI) tahun 2013 versi 3.0 dimensi environment (EN)dengan jumlah 30 item pengungkapan. Kemudian dilakukan penghitungan indeks pengungkapan tanggung jawab sosial Desy Mariani (2017).

CSRDi : Jumlah item informasi CSR yang diungkapkan / 30 item informasi CSR yang diungkapkan

\section{c. Variabel Intervening}

Variabel intervening yakni menggunakan kinerja keuangan yang merupakan variabel penyela/antara terletak di antara variabel independen dan dependen, sehingga variabel independen tidak langsung mempengaruhi. Dalam penelitian ini, indikator yang digunakan adalah Return on Asset (ROA). Desy Mariani,(2017).

$$
\text { ROA = Laba Setelah Pajak / Total Aset }
$$

\subsection{Model Penelitian}

Teknik analisa yang digunakan adalah path analysis menggunakan bantuan program eviews 9,5. Adapun persamaan yang digunakan adalah:

Persamaan $1: Y=a+\beta 1 X+e$

Persamaan2: $Z=a+\beta 2 X+\beta 3 Y+e$

Keterangan :

$\mathrm{a}=$ Konstanta

$\mathrm{B}=$ Koefisien Regresi

$\mathrm{X}=$ Green Accounting

$\mathrm{Y}=$ Corporate Social Responsibility Disclosure

$\mathrm{Z}=$ Kinerja Keuangan

$\mathrm{e}=$ error

\section{HASIL PENELITIAN}

a. Uji Asumsi Klasik

Uji asumsi pada penelitian ini, hipotesis diuji dengan menggunakan analisis regresi berganda (multiple regression analysis) dan analisis jalur (path analysis). Sebelum melakukan pengujian terhadap hipotesis, data dilakukan pengujian terhadap asumsiasumsi regresi linear atau uji asumsi klasik terlebih dahulu yang bertujuan untuk menghindari kesalahan.

\section{Uji Normalitas}

Keputusan terdistribusi normal tidaknya residual secara sederhana dengan membandingkan nilai Probabilitas JB (Jarque-Bera) hitung dengan tingkat alpha 0,05 (5\%). Apabila Prob. JB hitung lebih besar dari 0,05 maka dapat disimpulkan bahwa residual terdistribusi normal dan sebaliknya

\section{Persamaan 1}

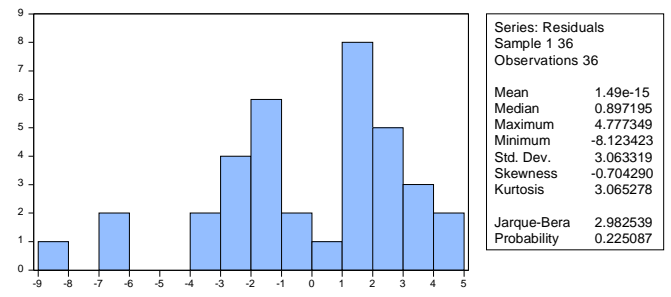

Sumber : Data diolaheviews 9,5

\section{Persamaan 2}

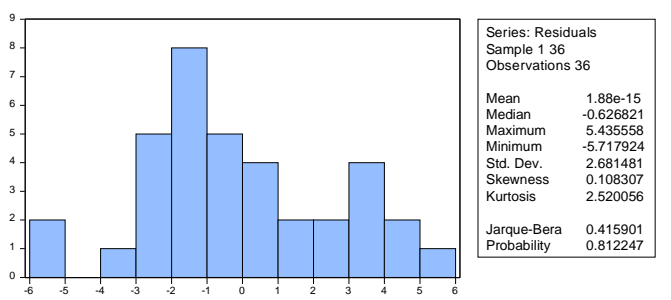

Sumber: Data diolaheviews 9,5

Nilai JB Probability hitung untuk persamaan 1 sebesar 0,225 > 0,05 dan Nilai JB Probability hitung untuk persamaan 2 sebesar $0,812>0,05$ sehingga dapat disimpulkan bahwa residual terdistribusi normal.

\section{Uji Multikolinieritas}

Uji multikolinearitas dapat dilihat dari nilai tolerance dan nilai varince inflation factors. Apabila tolerance $<0.10$ dan nilai VIF $>10$ artinya tidak terjadi multikolinearitas. 


\section{Persamaan 1}

Variance Inflation Factors

Date: 03/25/20 Time:00:57

Sample: 136

Included observations: 36

\begin{tabular}{cccc}
\hline \hline Variable & $\begin{array}{c}\text { Coefficient } \\
\text { Variance }\end{array}$ & $\begin{array}{c}\text { Uncentered } \\
\text { VIF }\end{array}$ & $\begin{array}{c}\text { Centered } \\
\text { VIF }\end{array}$ \\
\hline \hline C & 0.640678 & 5.142857 & NA \\
GREEN_ACCOUNTIN... & 0.795325 & 5.142857 & 1.000000 \\
\hline \hline
\end{tabular}

Sumber : Data diolaheviews 9,5

\section{Persamaan 2}

Variance Inflation Factors

Date: 03/25/20 Time: 01:20

Sample: 136

Included observations: 36

\begin{tabular}{cccc}
\hline \hline Variable & $\begin{array}{c}\text { Coefficient } \\
\text { Variance }\end{array}$ & $\begin{array}{c}\text { Uncentered } \\
\text { VIF }\end{array}$ & $\begin{array}{c}\text { Centered } \\
\text { VIF }\end{array}$ \\
\hline C & 0.012738 & 5.225440 & NA \\
KINERJA_KEUANGAN... & 0.000576 & 1.029051 & 1.004028 \\
GREEN_ACCOUNTIN... & 0.015626 & 5.163575 & 1.004028 \\
\hline
\end{tabular}

Sumber: Data diolaheviews 9,5

Berdasarkan hasil uji multikolinieritas di atas menunjukkan bahwa nilai Contered VIF variabel Green Acccounting 1,000000 dan Kinerja Keuangan 1,004028 kurang dari 10. Dengan demikian dapat disimpulkan bahwa dalam penelitian ini tidak terdapat hubungan linier antara variabel atau tidak terjadi multikolinieritas.

\section{Uji Heteroskedastisitas}

Keputusan terjadi atau tidaknya heterokedastisitas pada model regresi linier, apabila nilai Prob F hitung lebih besar dari tingkat alpha 0,05 (5\%) maka H0 diterima, sedangkan apabila nilai Prob.F hitung lebih kecil daripada tingkat alpha 0,05 (5\%) maka $\mathrm{H} 0$ ditolak.

\section{Persamaan 1}

Heteroskedasticity Test: Breusch-Pagan-Godrey

\begin{tabular}{llll}
\hline \hline & & & \\
F-statistic & 0.307024 & Prob. F(1,34) & 0.5831 \\
Obs ${ }^{*}$ R-squared & 0.322175 & Prob.Chi-Square(1) & 0.5703 \\
Scaled explained SS & 3.746670 & Prob. Chi-Square(1) & 0.0529 \\
\hline \hline
\end{tabular}

Sumber : Data diolaheviews 9,5

\section{Persamaan 2}

Heteroskedasticity Test:Breusch-Pagan-Godtrey

\begin{tabular}{|c|c|c|}
\hline F-statistic & 1.294277 Prob. F(2,33) & 0.2876 \\
\hline Obs*R-squared & 2.618482 Prob.Chi-Square(2) & 0.2700 \\
\hline Scaled explained SS & 5.995489 Prob.Chi-Square(2) & 0.0499 \\
\hline
\end{tabular}

Sumber : Data diolaheviews 9,5
Berdasarkan hasil uji heterokedastisitas menunjukkan bahwa nilai Prob $\mathrm{F}$ hitung persamaan 1 sebesar 0,583 lebih besar dari tingkat alpa 0,05 dan nilai prob $\mathrm{F}$ hitung persamaan 2 sebesar 0,288 lebih besar dari tingkat alpha $0,05 \quad(5 \%)$ sehingga berdasarkan uji hipotesis $\mathrm{H} 0$ dari kedua persamaan diterima yang artinya tidak terjadi heterokedastisitas..

\section{Uji Autokorelasi}

Untuk memastikan apakah model regresi linier terbebas dari autokorelasi, dapat menggunakan metode BG (Brusch Godfrey) atau LM (Lagrange Multiplier)Test

\section{Persamaan 1}

Breusch-Godfrey Serial Correlation LM Test:

\begin{tabular}{llll}
\hline \hline F-statistic & 0.469390 & Prob. F(2,32) & 0.6296 \\
Obs*R-squared & 1.026027 & Prob. Chi-Square(2) & 0.5987 \\
\hline \hline
\end{tabular}

Sumber : Data diolaheviews 9,5

\section{Persamaan 2}

Breusch-Godfrey Serial Correlation LM Test:

\begin{tabular}{llll}
\hline \hline & & & \\
F-statistic & 0.169151 & Prob. F(2,31) & 0.8452 \\
Obs*R-squared & 0.388626 & Prob. Chi-Square(2) & 0.8234 \\
\hline \hline
\end{tabular}

Sumber : Data diolaheviews 9,5

Berdasarkan hasil uji autokorelasi menunjukkan bahwa nilai prob $\mathrm{F}$ hitung persamaan 1 sebesar 0,630 dan untuk perhitungan nilai $\mathrm{F}$ hitung persamaan 2 sebesar 0,845 lebih besar dari tingkat alpha 0,05 sehingga dapat disimpulkan bahwa kedua persaman ini tidak terjadi autokorelasi. Kalaupun harus menggunakan uji DW (Durbin Watson) hasilnya pun sama yaitu tidak terjadi autokorelasi.

\section{Uji Linieritas}

Apabila nilai Prob. F hitung lebih besar dari tingkat alpha 0,05 (5\%) maka model regresi memenuhi asumsi linieritas dan sebaliknya, apabila nilai Prob. F hitung lebih kecil dari 0,05 maka dapat model tidak memenuhi asumsi linieritas.

\section{Persamaan 1 \\ Kamsey Ktst I I est \\ Equation: PERSAMAAN_PERTAMA \\ Specification: C KINERJA_KEUANGAN_Z_ _ GREEN_ACCOUNTING_X1 \\ Omitted Variables: Squares of fitted values}

\begin{tabular}{lccc}
\hline \hline & Value & df & Probability \\
\cline { 2 - 4 } t-statistic & 1.326605 & 33 & 0.1732 \\
F-statistic & 2.450859 & $(1,33)$ & 0.1732 \\
Likelihood ratio & 2.301635 & 1 & 0.1431 \\
\hline \hline
\end{tabular}

Sumber : Data diolah eviews 9,5 


\section{Persamaan 2}

Ramsey RESET Test

Equation: PERSAMAAN_KEDUA

Specification: CSR_DISCLOSURE_Y1_C KINERJA_KEUANGAN_Z _GREEN_ACCOUNTING_X1

Omitted Variables: Squares of fitted values

t-statistic

F-statistic

Likelihood ratio

\begin{tabular}{ccc} 
Value & df & Probability \\
\hline 0.901269 & 32 & 0.3742 \\
0.812287 & $(1,32)$ & 0.3742 \\
0.902417 & 1 & 0.3421
\end{tabular}

Sumber : Data diolaheviews 9,5

Berdasarkan hasil uji linieritas menunjukkan bahwa nilai F-statistic persamaan 1 sebesar 2,451 lebih besar dari 0,05 dan nilai F-statistic persamaan 2 sebesar 0,812 lebih besar dari 0,05 sehingga dapat disimpulkan bahwa model regresi telah memenuhi asumsi linieritas.

\section{b. Uji Hipotesis}

Untuk dapat menjawab hipotesis penelitian, maka digunakan dua alat analisis yaitu analisis regresi linear berganda dan analisis jalur

\begin{tabular}{|c|c|c|c|c|}
\hline \multicolumn{5}{|l|}{ 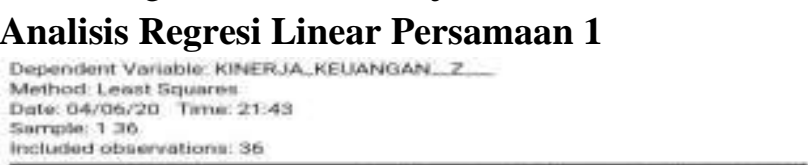 } \\
\hline Variabie & Coefficient & sut Error & t-Gtatistic & Prob. \\
\hline GREEN_ACCOUNTING $\times 1$ & $\begin{array}{l}0.501429 \\
0.330049\end{array}$ & $\begin{array}{l}0.800424 \\
0.891810\end{array}$ & $\begin{array}{r}0.738894 \\
-0.370089\end{array}$ & $\begin{array}{l}0.4650 \\
0.0136\end{array}$ \\
\hline R-sopuared & 0.004012 & \multicolumn{2}{|c|}{ Mean sependent var } & 0.32555 \\
\hline Adjusted fi-squered & 0.025282 & \multicolumn{2}{|c|}{ 8.0. dependent yor } & 20 \\
\hline 8E. of regression & 2117722 & \multicolumn{2}{|c|}{ Akaike info criterion } & 2 \\
\hline Sum squared resid & 152.4814 & \multicolumn{2}{|c|}{ Sefiwarz eriturion } & \\
\hline Log tikelibsod & -7706522 & \multicolumn{2}{|c|}{ Hannan-Quenn criter: } & 7 \\
\hline F-ptemistio & 0.136960 & \multirow{2}{*}{\multicolumn{2}{|c|}{ Dirbin-Watson stat }} & \\
\hline Prob(F-entatiatic) & 0.733611 & & & \\
\hline
\end{tabular}

Sumber: Data diolaheviews 9,5

Dari Tabel di atas maka didapatkan angka persamaan 1 sebagai berikut :

$$
\mathrm{Z}=\mathbf{0 , 5 9 1}+\mathbf{0 , 3 3 0} \mathrm{X1}+\mathrm{e}
$$

\section{Pembahasan:}

Variabel $\mathrm{Z}$ atau kinerja keuangan memiliki nilai coefficient 0,330 dan prob. 0.0136 .

\section{Analisis Regresi Linear Persamaan 2} Dependent Variable CSR_DiscLosuRE_Y1_

Date: 04/06/20. Time 2154

5ample: 136

Includec observations 36

\begin{tabular}{|c|c|c|c|}
\hline Variable & Coetticien & Std Frror t-Statistic & Prab \\
\hline $\begin{array}{c}\text { C } \\
\text { KINER_A KEUIANGAN } z \\
\text { GREEN ACCOUNTING X1 }\end{array}$ & $\begin{array}{l}0.020787 \\
0.235147 \\
0.458842\end{array}$ & $\begin{array}{ll}0.112864 & -0.184176 \\
0.023990 & 1.465036 \\
0.125003 & 3.670647\end{array}$ & $\begin{array}{l}0.0550 \\
0.0524 \\
0.0008\end{array}$ \\
\hline $\begin{array}{l}\text { R-squared } \\
\text { Aqqusted R-squared } \\
\text { SE. of regression } \\
\text { Sum squared resid } \\
\text { Log likelhood } \\
\text { F-statistic } \\
\text { Prob(F-statistic) }\end{array}$ & $\begin{array}{l}0.312484 \\
0.270817 \\
0.296240 \\
2.896021 \\
-5.718526 \\
7.499447 \\
0.002066\end{array}$ & $\begin{array}{l}\text { Mean dependent ver } \\
\text { S.D. dependert vat } \\
\text { Akaika info criterion } \\
\text { Schwarz criferion } \\
\text { Haman-Quirn eriter. } \\
\text { Durbin-Watson stat }\end{array}$ & $\begin{array}{l}0.360278 \\
0.346917 \\
0.484363 \\
0.616322 \\
0.530420 \\
2.044495\end{array}$ \\
\hline
\end{tabular}

Sumber : Data diolah eviews 9,5
Dari Tabel di atas maka didapatkan angka persamaan 2 sebagai berikut:

$$
\mathrm{Y}=-\mathbf{0 , 0 2 0}+\mathbf{0 , 4 5 9} \mathrm{X} 1+\mathbf{0 , 2 3 6} \mathrm{Z}+\mathrm{e}
$$

\section{Pembahasan :}

1) Variabel $\mathrm{X} 1$ atau green accounting memiliki coefficient 0,459 dan prob 0.0008 . Maka green accounting secara positif dan signifikan mempengaruhi Variabel Y atau Corporate Social Responsibility Disclosure.

2) Variabel $Z$ atau kinerja keuangan memiliki coefficient 0,236 dan prob 0,524. Maka kinerja keuangan mempengaruhi corporate social responsibility Disclosure secara positif dan signifikan.

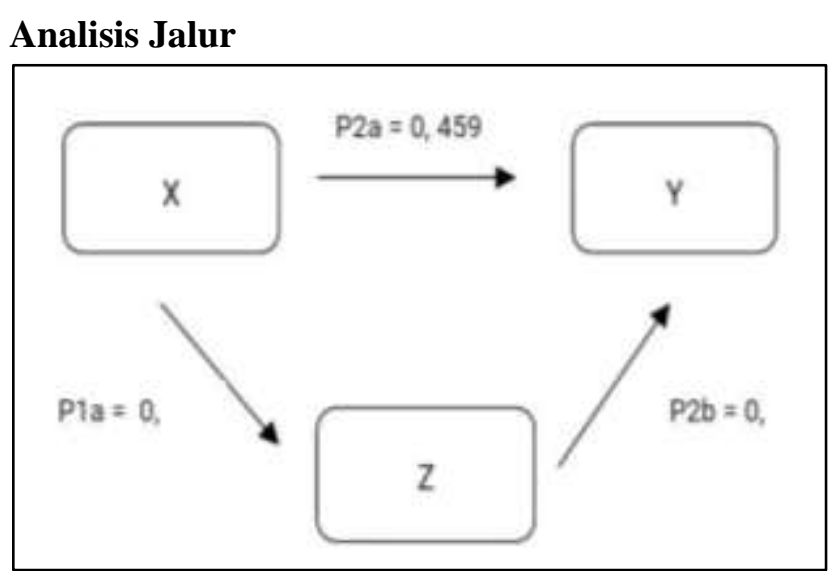

Sumber : Data diolah oleh peneliti

Berdasarkan analisis jalur pada gambar 6 maka menunjukan bahwa variabel $\mathrm{X}$ atau green accounting dapat berpengaruh langsung dan dapat pula berpengaruh tidak langsung terhadap $\mathrm{Y}$ corporate social responsibility disclosure pada bank umum syariah. Besarnya pengaruh langsung sebesar 0,459 sedangkan besarnya pengaruh tidak langsungnya yaitu (P1a) $x(P 2 b)=(0,330) \times(0,236)=0,078$. Pengaruh tidak langsung variabel $\mathrm{X}$ atau green accounting terhadap Y corporate social responsibility disclosure lebih kecil dibandingkan dengan nilai pengaruh langsungnya. Dari analisis jalur tersebut dapat disimpulkan bahwa variabel $\mathrm{Z}$ atau kinerja keuangan bukan merupakan variabel intervening atas variabel $\mathrm{X}$ atau green accounting terhadap Y corporate social responsibility disclosure.

\section{c. Interprestasi Hasil Penelitian}

Berdasarkan hasil pengolahan data yang telah dijelaskan sebelumnya, diperoleh hasil bahwa penelitian ini dapat membuktikan adanya pengaruh positif dan signifikan antara green accounting terhadap kinerja keuangan pada Bank Umum Syariah 


\section{Jurnal Ilmiah Ekonomi Islam, 6(03), 2020, 518}

di Indonesia (H1 diterima). Hasil tersebut konsisten dengan penelitian Anis Fitriani (2013) dan Nurika Restuningdiah (2010) yang berpendapat bahwa kinerja lingkungan berpengaruh positif terhadap kinerja keuangan. Hal ini dikarenakan penerapan green accounting setiap tahunnya tetap stabil dan cenderung meningkat setiap tahunnya, walaupun nilai Return On Assets (ROA) dari tersebut cenderung tidak stabil atau fluktuatif. Artinya, jika nilai rasio Return On Assets (ROA) semakin tinggi, maka semakin baik keadaan perusahaan.

Selanjutnya berdasarkan hasil pengolahan data yang telah dijelaskan sebelumnya, diperoleh hasil bahwa penelitian ini dapat membuktikan adanya pengaruh positif dan signifikan antara green accounting terhadap corporate social responsibility disclosure pada Bank Umum Syariah di Indonesia (H2 diterima). Hasil tersebut konsisten dengan penelitian Tino Anindito dan Didik Ardianto (2012) yang berpendapat bahwa kinerja lingkungan berpengaruh positif terhadap pengungkapan Corporate Social Responsibility. Hal ini dikarenakan dari tahun ke tahunnya makin banyak Bank Umum Syariah yang memberikan informasi mengenai aspek lingkungan berkelanjutan pada pelaporan keuangan perusahaannya yang diikuti dengan meningkatnya pengungkapan informasi aspek lingkungan pada tanggung jawab sosial di laporan keuangan perusahaan. Dengan demikian, jika perusahaan memberikan informasi yang meliputi kinerja lingkungan dan berkelanjutan yang baik pada pelaporan tahunannya maka perusahaan terbukti memiliki kepedulian sosial yang lebih besar terhadap masyarakat maupun tenaga kerjanya sehingga dapat juga meningkatkan nilai perusahaan.

Selanjutnya berdasarkan hasil pengolahan data yang telah dijelaskan sebelumnya, diperoleh hasil bahwa penelitian ini dapat membuktikan adanya pengaruh positif dan signifikan antara kinerja keuangan terhadap corporate social responsibility disclosure pada Bank Umum Syariah di Indonesia (H3 diterima). Hasil tersebut konsisten dengan penelitian Rizkia Anggita Sari (2012) yang berpendapat bahwa profitabilitas yang diukur oleh Return On Assets (ROA) memiliki pengaruh secara positif terhadap pengungkapan corporate social responsibility disclosure. Hal ini dikarenakan pengungkapan tanggung jawab sosial pada laporan keuangan dapat menjadi pertimbangan investor dalam berinvestasi, karena didalamnya mengandung informasi sosial perusahaan mengungkapkan informasi keuangan yang berkaitan dengan lingkungan akan lebih menarik para pengguna laporan keuangan sehingga akan menaikan kinerja ekonomi perusahaan yang bersangkutan sehingga para stakeholder maupun pengguna laporan keuangan akan lebih tertarik pada Bank Umum Syariah.

Selanjutnya berdasarkan hasil pengolahan data analisis jalur yang telah dijelaskan sebelumnya, diperoleh hasil bahwa penelitian ini dapat membuktikan bahwa kinerja keuangan bukan merupakan variabel intervening atas Green Accounting terhadap Corporate Social Responsibility Disclosure (H4 ditolak). Hasil tersebut tidak konsisten dengan penelitian Mazda Eko Sri Tjahjono (2013) yang berpendapat bahwa kinerja keuangan merupakan variabel intervening atas kinerja lingkungan terhadap Corporate Social Responsibility Disclosure. Hal tersebut bisa disebabkan karena adanya perbedaan objek penelitian atau periode penelitian. Hal lain juga mungkin disebabkan, karena penilaian indikator green accounting cenderung stabil dan meningkat tiap tahun,diikuti dengan meningkatnya penilaian indikator corporate social responsibility disclosure, namun pada penilaian indikator kinerja keuangan yang diyakini adalah Return On Assets (ROA) cenderung tidak stabil atau fluktuatif.

Selanjutnya berdasarkan hasil analisis deskriptif, Dalam perspektif Islam, adanya penerapan green accounting atau sustainbility reporting sudah menjadi suatu aturan yang nyata sebelum adanya konsep green accounting. Bank syariah sudah seharusnya berada pada barisan terdepan dalam pelaksanaan green accounting, terutama soal pelaporan tahunannya yakni sustainbility reporting yang pada laporan tahunannya melampirkan segala aspek, termasuk tanggung jawab sosialnya untuk keberlanjutan ekonomi dan lingkungan. Bank syariah juga cukup selektif dalam memberikan pembiayaannya agar tepat sasaran dan tentunya tidak merusak lingkungan. Dalam kebijakan prosedur operasional bank syariah, adanya mekanisme screening pembiayaan dan investasi menetapkan negative list usaha haram seperti alkohol, persenjataan, perjudian, usaha berdampak kerusakan moralitas, juga kegiatan bisnis nyata yang berdampak mengancam kelestarian lingkungan hidup keberlanjutan. Bank Indonesia (BI) akan segera menerbitkan PBI tentang bank ramah lingkungan. Pada landasan teori Al-Maqashid al-Syariah menurut Ash-Syatibi yang telah dihitung juga oleh ulama 
dengan nama al-kulliyat al khams (lima hal ini/pokok) yang mengungkapkan tentang kemaslahatan hamba, baik didunia maupun di akhirat. Ada 5 hal inti yang harus dijaga dan dilindungi dalam maqashid al-syariah (Abu Ishaq Ibrahim bin Musa bin Muhammad Allakhmy As-Syatiby , 2003 : 78), yaitu:

1) Menjaga Agama (Hifdz ad-Din)

2) Menjaga Jiwa (Hifdz an-Nafs)

3) Menjaga Akal (Hifdz al-Aql)

4) Menjaga Harta (Hifdz al-Mal)

5) Menjaga Keturunan (Hifdz an-Nasl)

Artinya, tujuan dari konsep green accounting tidak lain dan tidak bukan untuk mewujudkan kemaslahatan hamba dengan cara ikut menjaga lingkungan dan alam dibidang korporasi atau bisnis. Selain itu juga, green accounting bukan hanya terfokus untuk menjaga alam saja, melainkan kelima inti tersebut yaitu menjaga agama dari larangan larangan yang diperbuat, menjaga jiwa orang banyak, menjaga akal manusia dari perbuatan yang kurang baik, menjaga harta yang ada dibumi, serta menjaga keturunan agar mereka juga dapat menikmati kekayaan alam. Hal ini juga merupakan suatu bentuk tanggung jawab sosial perusahaan terhadap sosial, ekonomi, maupun lingkungan dan alam. Adapun firman Allah SWT yang menjelaskan tentang menjaga lingkungan yang tertuang pada Q.S Ar - Ruum ayat 41, yang berbunyi :

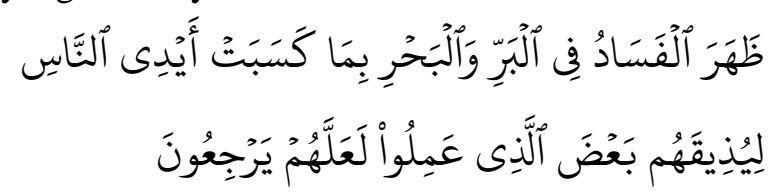

Yang artinya: "Telah nampak kerusakan di darat dan di laut disebabkan karena perbuatan tangan manusi, supay Allah merasakan kepada mereka sebahagian dari (akibat) perbuatan mereka, agar mereka kembali (ke jalan yang benar)".

Hal ini membuktikan bahwa menjaga lingkungan dalam Islam adalah sebuah keharusan dan ada pengaruhnya demi kemaslahatan bagi taraf hidup orang banyak. Dengan demikian, peneliti berpendapat bahwa konsep green accounting terhadap corporate social responsibility pada Bank Umum Syariah sudah sesuai dengan perspektif Islam baik dalam pelaksanaan maupun penilaiannya.

\section{KESIMPULAN}

Setelah dilakukan pengolahan data penelitian dan analisisnya, maka dapat disimpulkan hasil penelitian ini adalah sebagai berikut: a. Green Accounting memiliki pengaruh positif dan signifikan terhadap Kinerja Keuangan dan Corporate Social Responsibility Disclosure pada Bank Umum Syariah di Indonesia. Dibuktikan dengan green Accounting memiliki coefficient 0,459 dan prob 0.0008 .

b. Kinerja Keuangan memiliki pengaruh positif dan signifikan terhadap Corporate Social Responsibility Disclosure pada Bank Umum Syariah di Indonesia. Dibuktikan dengan kinerja keuangan memiliki coefficient 0,236 dan prob 0,524 .

c. Kinerja Keuangan bukan merupakan Variabel Intervening atas Green Accounting terhadap Corporate Social Responsibility Disclosure. Dibuktikan dengan besarnya pengaruh langsung sebesar 0,459 sedangkan besarnya pengaruh tidak langsungnya yaitu $(\mathrm{P} 1 \mathrm{a}) \times(\mathrm{P} 2 \mathrm{~b})=(0,330) \mathrm{x}$ $(0,236)=0,078$. Pengaruh tidak langsung variabel $\mathrm{X}$ atau green accounting terhadap $\mathrm{Y}$ corporate social responsibility disclosure lebih kecil dibandingkan dengan nilai pengaruh langsungnya

d. Green accounting terhadap CSR Disclosure dan kinerja keuangan sudah sesuai dengan perspektif Islam baik dalam pelaksanaan maupun penilaiannya

\section{UCAPAN TERIMAKASIH}

Penulis mengucapkan terimakasih kepada berbabagai pihak yang telah mendukung sehingga terselesaikannya skripsi ini. Terimakasih.

\section{REFERENSI}

Abu Ishaq Ibrahim bin Musa bin Muhammad Allakhmy As-Syatiby. 2003. Kitab Al Muwafaqoot. Penerbit Dar Ibn Qayyim.

Andi Nurul Fadhilah Ayu, Maria Anityasari. 2013. "Analisis Implementasi Green BankingPada PT Bank X (Persero)Tbk..”Jurnal Teknik Pomits. Vol.1, No.1

Anis Fitriani. 2013. "Pengaruh Kinerja Lingkungan Dan Biaya Lingkungan Terhadap Kinerja Keuangan pada BUMN. "Jurnal Ilmu Manajemen, Vol. 1, No.1.

Chariri A dan Ghozali Imam. 2007. Teori Akuntansi.

Semarang : Badan Penerbit Universitas Diponegoro.

Cahyani, D. I., \& Sumadi, S. (2015). Alternatif Sistem Ekonomi Islam Untuk Indonesia Yang Lebih Sejahtera. Jurnal Ilmiah Ekonomi Islam, 1(02). 


\section{Jurnal Ilmiah Ekonomi Islam, 6(03), 2020, 520}

Darwin, Ali. 2007. Pentingnya Laporan Keberlanjutan, Akuntan Indonesia, 3 (1), 14-142007.

Desi Mariani. 2017. Pengaruh Penerapan Green Accounting, Kepemilikan Saham Publik, Publikasi CSR terhadap Pengungkapan CSR dengan Kinerja Keuangan sebagai Variabel Intervening (Studi Empiris pada Perusahaan Property dan Real Estate yang terdaftar di Bursa Efek Indonesia Tahun 2011-2015)

Djakfar, Muhammad. 2007. Etika Bisnis Dalam Perfektif Islam. Malang: UIN Malang Press.

Edoardus Satya Adhiwardana dan Daljono. 2013. "Pengaruh Corporate Social Responsibility dan Kepemilikan Asing terhadap Kinerja Perusahaan. "Diponegoro Journal of Accounting, Vol.2, No.2.

Ersi Sisdianto dan Ainul Fitri. 2020. "Pengaruh Firm Growth AndFirm Value On Corporate Social Responsibility In Indonesia (Survey Pada Bank Mandiri And Bank Mandiri Syariah Tahun 20142018), “Jurnal Akuntansi dan Keuangan Islam, Vol.1, No. 1

Fitria Puji Astuti et.al. 2014. "Pengaruh Kinerja Lingkungan Dan Kepemilikan Asing Terhadap Kinerja Keuangan."Accounting Analysis Journal, Vol.3, No.4.

Lako, Andreas. 2014 Green Economy Menghijaukan Ekonomi, Bisnis, dan Akuntansi Jakarta : Erlangga.

M.Rachman, Nurdizal dan Efendi, Asef dan Wicaksana, Emir. 2011. Paduan Pelaksanaan Corporate Social Responsibility. Jakarta: Penebar Swadaya.

Mazda Eko Sri Tjahjono. 2013. "Pengaruh Kinerja Lingkungan Terhadap Nilai Perusahaan dan Kinerja Keuangan. “Jurnal Ekonomi, Vol. 4, No. 1.

Muhammad, Etika Bisnis Islam. 2004. Yogyakarta : Unit Penerbit dan Percetakan YPKN.
Nurika Restuningdiah. 2014. "Kinerja Lingkungan terhadap Return On Assets melalui Corporate Social Responsibility, "Jurnal Keuangan dan Perbankan, Vol. 14, No. 2.

Rizkia Anggita Sari. 2012. "Pengaruh Karakteristik Perusahaan Terhadap Corporate Social Responsibility Disclosure Pada Perusahaan Manufaktur Yang Terdaftar Di Bursa Efek Indonesia. "Jurnal Nominal, Vol. 1, No. 1.

Setyo Budiantoro. 2014. Mengawal Green Banking Di Indonesia Dalam Rangka Pembangunan Berkelanjutan. Jakarta: Perkumpulan Prakarsa.

Sutojo, Siswanto. 2007. Manajemen Terapan Bank. Jakarta: Pustaka Binaman Pressindo.

Tino Anindito dan Didik Ardianto. 2012. "Pengaruh Kinerja Lingkungan Terhadap Corporate Social Responsibility (CSR) Disclosure dan Kinerja Finansial Perusahaan Kimia dan Pertambangan Yang Terdaftar Di Bursa Efek Indonesia (Studi Empiris Pada Perusahaan Pertambangan Yang Terdaftar dalam BEI 2007 sampai 2010). "Diponogoro Journal Of Accounting. Vol. 2, No.1.

Tria Ratnasari, Arni Surwanti, Firman Pribadi. "Model Integrasi untuk Mengukur Dampak dari Green Banking dan Kinerja Keuangan Terhadap Profitabilitas Bank.

Widya Novita Sari, Puspita Rani, 2015. "Pengaruh Kepemilikan Institusional, Kepemilikan Manajerial, Return On Assets (ROA) Dan Ukuran Perusahaan Terhadap Pengungkapan Corporate Social Responsibility (CSR) Pada Perusahaan Manufaktur Yang Terdaftar Di Bursa Efek Indonesia Periode 2011-2013. "Jurnal Akuntansi dan Keuangan. Vol. 4, No. 1.

Yusuf, Muhammad Yasir. 2017. Islamic Social Responsibility I-CSR pada Lembaga Keuangan Syariah LKS. Depok: Prenadamedia Group. 